\title{
Operacja kijowska 1920 roku Tomasz Grzegorczyk, Wyprawa kijowska, Wydawnictwo Adam Marszalek, Toruń 2014, ss. 256
}

\begin{abstract}
$\mathrm{O}$ statnie 25 lat przyniosło daleko idące przeobrażenia we wszystkich dziedzinach życia politycznego, społecznego, gospodarczego i naukowego Europy Środkowej i Wschodniej. Nowe zjawiska i procesy odnotowano również w polskiej nauce historyczno-wojskowej. Straciły na znaczeniu istniejące w PRL-u uwarunkowania polityczne i ideologiczne oraz idące za nimi wytyczne i ograniczenia cenzuralne, które skłaniały do podejmowania jedynie tematów zgodnych z marksistowsko-leninowską wykładnią dziejów państw i narodów. Zniknęły tematy tabu, wśród których była także wojna polsko-sowiecka z lat 1919-1920.

Widoczna od początku lat 90. XX w. intensyfikacja badań sprawiła, iż szybko powiększa się piśmiennictwo poświęcone militarnym aspektom odrodzenia Polski w latach 1914-1921. Opracowana przez zespół pracowników Centralnej Biblioteki Wojskowej w 1998 r. specjalistyczna bibliografia zawiera 9717 publikacji: drukowanych zbiorów dokumentów, relacji i wspomnień, syntez, monografii, artykułów naukowych, opracowań przyczynkarskich, tomów materiałów z konferencji i sympozjów naukowych, prac publicystycznych i albumów. Wśród wskazanych prac aż 4712 dotyczy okresu 1918-1921, kiedy odradzało się Wojsko Polskie i toczono wojny o niepodległość i granice ${ }^{1}$. Bibliografia CAW nie jest kompletna, o czym zresztą informują jej autorzy, pisząc, iż ich dzieło „[...] rejestruje około 10 tys. wybranych publikacji krajowych i zagranicznych z lat 1910-1998,
\end{abstract}

${ }^{1}$ Militarne aspekty odrodzenia Rzeczypospolitej 1914-1921. Bibliografia, t. 1-2, Warszawa 1998. 
wydanych na ziemiach polskich w granicach przedrozbiorowych oraz polonica zagraniczne, odnoszące się do tej problematyki"2. W chwili obecnej liczba publikacji - krajowych i zagranicznych - dotyczących tylko wojny polsko-sowieckiej 1919-1920 przekroczyła zapewne kilka tysięcy pozycji. Gros prac to sensu stricto opisy działań bojowych: począwszy od szczebla najniższego - taktycznego, kończąc na rozważaniach o charakterze operacyjnym i strategicznym.

Wśród nich znaczące miejsce znalazła operacja kijowska przeprowadzona późną wiosną 1920 r. przez Wojsko Polskie wraz ze swoim sprzymierzeńcem - siłami zbrojnymi Ukraińskiej Republiki Ludowej pod dowództwem Głównego Atamana Symona Petlury. W polskiej i sowieckiej (rosyjskiej) historiografii wspomniana operacja często nazywana jest „wyprawą kijowską". Takiego terminu użył Tadeusz Kutrzeba, jej uczestnik i równocześnie autor monumentalnej monografii ${ }^{3}$. Trafna jest ocena Tomasza Grzegorczyka, że ,[...] mimo wysiłków czynionych, szczególnie po 1989 r., przez polską historiografię do tej pory nie powstało dzieło poświęcone ofensywie kijowskiej o wartości przewyższającej dokonania T. Kutrzeby"4.

O ,wyprawie kijowskiej” pisali także inni polscy historycy i publicyści, m.in. Włodzimierz Bączkowski ${ }^{5}$, Juliusz Bandrowski-Kaden ${ }^{6}$, Tadeusz Machalski ${ }^{7}$, Włodzimierz Paźniewski ${ }^{8}$, Klemens Rudnicki ${ }^{9}$, Marian Romeyko $^{10}$, Mieczysław Wrzosek ${ }^{11}$, Krzysztof A. Tarkowski ${ }^{12}$, Wiesław Walkiewicz $^{13}$, Adam J. Dąbrowski ${ }^{14}$ i inni.

2 Ibidem, s. 7.

3 T. Kutrzeba, Wyprawa Kijowska 1920 roku, Warszawa 1937.

4 T. Grzegorczyk, Wyprawa kijowska, Toruń 2014, s. 10.

5 W. Bączkowski, Wyprawa kijowska, „Biuletyn Polsko-Ukraiński” 1937, nr 20.

6 J. Bandrowski-Kaden, Trzy wyprawy, Wrocław 1991, s. 65-109 (Wyprawa na Kijów).

7 T. Machalski, Wyprawa kijowska, ,Horyzonty” 1968, nr 147, s. 65-71.

8 W. Paźniewski, Wyprawa kijowska: na czym polegała gra Pitsudskiego, „Rzeczypospolita Podchorążacka” (Londyn) 1991, nr 41, s. 29-31.

9 K. Rudnicki, Wyprawa kijowska a „,blitzkrieg”, „Przegląd kawalerii i Broni Pancernej” (Londyn) 1958/1959, nr 11, s. 101-104.

${ }^{10}$ M. Romeyko, Lotnictwo w wyprawie kijowskiej, „Lot” 1937, nr 6, s. 4.

11 M. Wrzosek, Wojny o granice Polski Odrodzonej 1918-1921, Warszawa 1992; idem, Wyprawa kijowska 1920, „Polska Zbrojna. Magazyn tygodniowy” 1992, nr 18, s. 1.

12 K. A. Tarkowski, Wyprawa kijowska 1920, ,Skrzydlata Polska” 1990, nr 28, s. 12 i nr 29, s. 12.

13 W. Walkiewicz, Wobec ,wyprawy kijowskiej”, „Rzeczywistość” 1988, nr 16, s. 8.

14 A. J. Dąbrowski, 5 pułk ułanów w wyprawie kijowskiej 1920 r., „Ułan Pasławski” 1957, z. 4, s. 1-7. 
Pojęcie „wyprawa kijowska” występuje także w historiografii naszych wschodnich sąsiadów ${ }^{15}$. Dla historyków sowieckich (rosyjskich) jest ono bardzo użyteczne, gdyż umożliwia znacznie mocniej akcentować kwestie polityczne wydarzeń, które miały miejsce wiosną i latem 1920 r. Negliżując walki prowadzone przez Wojsko Polskie z Armią Czerwoną w 1919 r., przedstawiają polsko-ukraiński marsz na Kijów w kwietniu 1920 r. jako „agresję burżuazyjno-obszarniczej Polski"16 i początek wojny polsko-sowieckiej. Pozwala to oskarżać Polskę o wywołanie wojny w kwietniu 1920 r., o tendencje imperialistyczne, o chęć odbudowy Rzeczypospolitej w granicach sprzed rozbiorów, od Morza Bałtyckiego do Morza Czarnego. Można permanentnie odgrzewać stalinowską tezę, że rozpętując wojnę, imperialiści polscy spodziewali się rozszerzyć granice burżuazyjno-obszarniczej Polski od Gdańska do Odessy i przy pomocy białogwardyjskich wojsk Wrangla zagarnąć Białoruś i Ukrainę. W zamian za to Polska przyrzekła Wranglowi pomoc w rozgromieniu wojsk sowieckich i przywróceniu burżuazyjno-obszarniczego ustroju w Rosji ${ }^{17}$. Twierdzenia te nie były poparte żadnymi dowodami. Nie miało to jednak żadnego znaczenia. O ich żywotności świadczy to, że pojawiają się, mimo że od epoki stalinowskiej upłynęło kilka dziesięcioleci. Na przykład Lew Nikulin w biografii Michaiła Tuchaczewskiego, wydanej najpierw w ZSRR w 1963 r., a potem po przetłumaczeniu w Polsce w 1965 r., twierdził, że wojna rozpoczęła się dopiero w kwietniu 1920 r.: „Już 8 kwietnia 1920 r. rząd radziecki przekonał się, że pertraktacje z burżuazyjną Polską nie budzą żadnych nadziei. [...] Wybuch wojny między Republiką Radziecką a burżuazyjną Polską był nieunikniony. [...] 25 kwietnia 1920 r. [...] rozpoczęły się działania wojenne Polski burżuazyjnej przeciwko radzieckiej Ukrainie..."18. Identycznie problem ten widzą W. A. Załotariew, O. W. Saksonow i S. A. Tiuszkiewicz, autorzy wydanej w 2001 r. pracy pt. Военная история России ${ }^{19}$. Opisując przebieg wojny domowej w Rosji, ani słowem nie wspominają o toczonych w 1919 r. walkach polsko-sowieckich. Czytelnik dowie się jedynie,

15 M.in. w publikacjach Nikołaja Kakurina, K. Bernedsa i Władymira Melikowa. Zob. Н. Какурин, К. Берендс, Кииевская операия Поляков в 1920 г., Москва 1928; Н. Какурин, В. Меликов, Гражданская война в Росснн: война с белополяками, Москва 2002.

16 Гражданская война в ССС, t. 2, Москва 1986, s. 260.

17 Zob. Historia Wszechzwiązkowej Komunistycznej Partii (Bolszewików). Krótki kurs, Warszawa 1949, s. 273.

${ }_{18}$ L. Nikulin, Tuchaczewski, Warszawa 1965, s. 112.

19 В. А. Золотарев, О. В. Сақсонов, С. А. Тюшқевич, Военная история России, Мосқва 2001. 
że 17 kwietnia 1920 r. marszałek Józef Piłsudski wydał rozkaz wykonania operacji zaczepnej na Wołyniu i Podolu, której celem było rozbicie sowieckich 12 i 14 Armii, wchodzących w skład Południowo-Zachodniego Frontu. A sama operacja rozpoczęła się 25 kwietnia 1920 r. uderzeniem polskich wojsk na Ukrainie ${ }^{20}$. Analogicznie postąpili autorzy wielotomowego dzieła pt. История гражданской войны в ССС ${ }^{21}$, którzy prezentując przebieg wojny domowej i walki z obcą interwencją w 1919 r., nie podali, że już na początku tego roku rozpoczęła się wojna z Polską ${ }^{22}$. W Rosji, podobnie jak w Polsce, są także historycy, którzy piszą, że wojna polsko-sowiecka toczyła się tylko w 1920 r. Do nich należy A. W. Sziszow, który w swojej książce prezentującej najważniejsze konflikty zbrojne XX w. zamieścił rozdział, któremu nadał tytuł Советско-польская война (1920)²3.

Politycy i historycy sowieccy starali się również utrwalić pogląd, że Polska, rozpoczynając wojnę z Rosją Sowiecką, wykonywała dyrektywy Ententy. Eksponowano słowa Lenina, który twierdził, że „Ententa posługiwała się Polską jako narzędziem w nowej próbie zniszczenia Republiki Radzieckiej”"24. Upowszechniano głoszoną przez niego tezę, iż „Wojna ta stanowi jedno z ogniw długiego łańcucha wydarzeń oznaczających wściekły opór międzynarodowej burżuazji wobec zwycięskiego proletariatu, wściekłą próbę międzynarodowej burżuazji zmierzającej do zdławienia Rosji Radzieckiej, do obalenia pierwszej Władzy Radzieckiej, za wszelką cenę, wszelkimi środkami" 25 . Jeszcze w latach 70. we wstępie do tomu dokumentów pt. Директивы командования фронтов Красной Армии (1917-1922 22.), pisano, że polscy militaryści i niedobitki białych wojsk pod dowództwem Wrangla, stanowią dwie ręce międzynarodowego imperializmu dążące do zduszenia władzy sowieckiej ${ }^{26}$.

Szerokie stosowanie terminu „wyprawa kijowska” w polskich i sowieckich (rosyjskich) pracach naukowych i w publicystyce prawdopodobnie skłoniło Tomasza Grzegorczyka do użycia tego pojęcia w tytule własnej

20 Ibidem, s. 550.

${ }^{21}$ История гражданской войны в ССС, Москва 1957.

22 Ibidem, Т. 3: Упрочение советской власти.Начало иностранной военной интервенции и гражданской войны, Москва 1957.

23 А. В. Шишов, Советско-польская война (1920). ОтЮжной Африки до Чечни, Москва 2006, s. 142-155.

${ }^{24}$ W. I. Lenin, Dzieła, t . 31: Kwiecień - grudzień 1920. Przekład z 4 wyd. ros. przygot. przez Instytut Marksa - Engelsa - Lenina przy KC WKP(b) Warszawa 1955, s. 305.

25 Ibidem, s. 118.

26 Директивы командования фронтов Красной Армии (1917-1922 г2.). Т. III: Апрель 1920 г.-1922 г., Моква 1974, s. 3, 
monografii. Nie wziął pod uwagę, że z punktu widzenia sztuki wojennej znacznie trafniejszy byłby tytuł „operacja kijowska 1920 r.”. Wtedy jednak musiałby gros uwagi poświecić czysto wojskowej analizie wspomnianej operacji. Autor nie zamierzał jednak takiego dzieła stworzyć. We wstępie pracy poinformował, iż „Praca, którą oddaję do rąk Czytelnika, nie jest monografią i do tego miana pretensji nie rości. Powstała w znaczącej części w wyniku przemyśleń i kwerendy przeprowadzonych na potrzeby badań nad dziejami 6 Armii WP. Część materiałów wówczas uzyskanych, a następnie $\mathrm{w}$ trakcie pisania uzupełnionych, które $\mathrm{z}$ różnych względów nie zostały wówczas w ogóle albo w całości wyzyskane, a które wydawały się warte wykorzystania, posłużyły jako podstawa źródłowa do napisania niniejszej książki”27.

Tłumaczenie autora, że jego praca ,[...] nie jest monografią i do tego miana pretensji nie rości”, skłania do zadania pytania, czym wobec tego jest książka nosząca tytuł Wyprawa kijowska? Gdyby potraktować słowa autora expressis verbis, to jego opracowanie nie było planowane jako samodzielne przedsięwzięcie badawcze i edytorskie, lecz powstało $w$,znaczącej części w wyniku przemyśleń i kwerendy przeprowadzonych na potrzeby badań nad dziejami 6 Armii WP”, podstawą źródłową zaś były materiały, „które z różnych względów nie zostały wówczas w ogóle albo w całości wyzyskane". W uproszczeniu można powiedzieć, iż T. Grzegorczyk podczas przygotowywania monografii 6 Armii Wojska Polskiego w 1920 r. (ukazała się w 2009 r. $)^{28}$, nie spożytkował całości zebranych materiałów, uznał więc, iż ich „resztówka” posłuży do napisania kolejnej książki.

$\mathrm{Z}$ zasady we Wstepie publikacji naukowych ich autor (autorzy) precyzują cele badawcze, jakie zamierzają osiągnąć, a w Zakończeniu dokonują rozliczenia swojej deklaracji. Tomasz Grzegorczyk świetnie o tym wie, gdyż wspomniane prawidła badawcze zawarł w monografii 6 Armii. We wstępie wskazał cel, ,jaki przyświecał powstaniu pracy”29, natomiast w obszernym zakończeniu zrelacjonował swoje badawcze osiągnięcia ${ }^{30}$.

Inaczej postąpił w Wyprawie kijowskiej. W ostatnim akapicie wstępu autor a priori stwierdził: „Ustalenia o charakterze naukowym, zawarte w tej publikacji, choć skromne, wypełniają cele, jakie przyświecały jej powstaniu"31. Wcześniej jednak ani słowem o tych celach nie wspomniał.

27 T. Grzegorczyk, Wyprawa ..., s. 14.

28 T. Grzegorczyk, 6. Armia Wojska Polskiego w 1920 r., Toruń 2009.

29 Ibidem, s. 26.

${ }^{30}$ Ibidem, s. 409-420.

31 T. Grzegorczyk, Wyprawa..., s. 15. 
Na postawie czego ma więc czytelnik ocenić, czy cele „choć skromne”, zostały zrealizowane? Od autora nie otrzyma w tym zakresie żadnej pomocy, gdyż książka nie ma Zakończenia. Czyli nie posiada jednego z najważniejszych elementów składających się na publikację naukową.

Brak jasnej koncepcji pracy uwidocznił się $\mathrm{w}$ jej konstrukcji. Podzielona została na trzy nierówne pod względem wielkości rozdziały. Najobszerniejszy jest rozdział drugi zatytułowany Wyprawa na Kijów, który zajmuje 77 stron. To zrozumiałe, gdyż jest to kwintesencja opracowania. Dyskusyjne jest natomiast poświęcanie aż 70 stron (tyle liczy rozdział pierwszy, czyli niewiele mniej niż rozdział drugi, znacznie ważniejszy) politycznemu krajobrazowi Europy po I wojnie światowej.

Truizmem jest stwierdzenie, iż wojna jest kontynuacją polityki. Już trzy wieki temu zwrócił na to uwagę Carl von Clausewitz, pruski teoretyk wojskowy, który napisał, że „Wojna jest [...] aktem przemocy, mającym na celu zmuszenie przeciwnika do spełnienia naszej woli" ${ }^{2}$, dodając następnie, że ,[...] wojna jest nie tylko czynem politycznym, lecz i prawdziwym narzędziem polityki, dalszym ciągiem stosunków politycznych, przeprowadzeniem ich innymi środkami" ${ }^{33}$. Nie można jej postrzegać wyłącznie jako sumy działań militarnych, gdyż obejmuje ona i inne dziedziny życia politycznego, społecznego i ekonomicznego. Nigdy wojna nie jest operacją czysto militarną, czyli sumą bitew czy kampanii, lecz takim stanem społeczeństwa, w którym ostry konflikt z jakąś grupą zewnętrzną lub ostry konflikt wewnętrzny znajduje potwierdzenie w starciu orężnym.

Batalia o niepodległość Polski i o jej kształt terytorialny toczyła się dwa i pół roku, od listopada 1918 r. do czerwca 1921 r. Nie ma jednak najmniejszej wątpliwości, że przełomowe wydarzenia miały miejsce późną wiosną i latem $1920 \mathrm{r}$. A ich wyjątkowo ważnym fragmentem był polsko-ukraiński marsz na Kijów. Wtedy to rozstrzygnęły się trwające już ponad rok zmagania polsko-sowieckie. Pokonanie Polski było bowiem dla bolszewików najistotniejszym krokiem na drodze do zrealizowania zasadniczego zadania politycznego - eksportu rewolucji do krajów Europy Zachodniej. Inne cele - chociaż ważne - nie odgrywały tak decydującej roli. Z kolei dla odrodzonej w 1918 r. Polski takim najistotniejszym pragnieniem było zapewnienie sobie bezpiecznej granicy na Wschodzie i objęcia nią większości ziem należących ongiś do Rzeczypospolitej, na których znajdowały się duże skupiska ludności polskiej. Dążyła więc do osłabienia Rosji (nieważne przy tym było, czy będzie to Rosja bolszewicka, czy też Rosja „biała”)

32 C. von Clausewitz, O wojnie, t. 1, Warszawa 1958, s. 15.

33 Ibidem, s. 32. 
przez zrealizowanie idei połączenia rzeczywistym federacyjnym węzłem Polski, Ukrainy i Białorusi, a nawet w sprzyjających okolicznościach Litwy. Wysiłki Rzeczypospolitej do zapewnienia sobie bezpieczeństwa na wschodniej granicy zderzały się z realizowanym przez kierownictwo polityczno-wojskowe sowieckiej Rosji, niemal od pierwszych dni po zdobyciu przez bolszewików władzy, planem eksportu rewolucji proletariackiej, najpierw w głąb Europy, a docelowo na cały świat.

Słusznie więc T. Grzegorczyk uznał, iż należy pokazać polityczne tło konfliktu polsko-sowieckiego i jego międzynarodowe uwarunkowania oraz odsłonić przyczyny i okoliczności, które doprowadziły do zawarcia 21 kwietnia 1920 r. sojuszu polsko-ukraińskiego i wspólnej operacji wojskowej, która w następnym miesiącu doprowadziła do opanowania Kijowa. Czy jednak nie przesadził w prezentowaniu sytuacji państw, które z kwestią ukraińską, stosunkami polsko-ukraińskimi, sojuszem Piłsudski-Petlura i „wyprawą kijowską" niewiele miały wspólnego. Chodzi szczególnie o państwa bałtyckie: Finlandię, Łotwę, Estonię i Litwę. Omówienie ich położenia geopolitycznego i możliwości militarnych zajęło przeszło 20 stron (od 38 do 60). Do tego kilka następnych (od 61 do 67) przeznaczył na zaprezentowanie kwestii białoruskiej i opisanie polskich kontaktów z białoruskimi środowiskami niepodległościowymi. W sumie z liczącego 70 stron pierwszego rozdziału pracy aż 28 nie ma bezpośredniego związku z problematyką „,wyprawy kijowskiej”.

Wątpliwości wzbudzają także niektóre tezy prezentowane przez autora. Chodzi o stosunek państw bałtyckich do wojny polsko-sowieckiej i możliwość wykorzystania ich sił zbrojnych przeciwko Armii Czerwonej wiosną 1920 r. Na przykład T. Grzegorczyk przekonuje czytelnika, iż „, ...] można prawdopodobnie założyć, że Finlandia (po hipotetycznym zawiązaniu sojuszu z Estonią, Łotwą i Polską) wystawiłyby na front przeciwbolszewicki trzy dywizje piechoty, Estonia trzy, Łotwa i Litwa kolejne pięć dywizji oraz, że z kawalerii w dyspozycji wspomnianych państw wyłoniłaby się łącznie także siła równa co najmniej polskiej dywizji jazdy. Wraz z artylerią pozostającą w dyspozycji tych, niestety, niedoszłych aliantów Polski dałoby to jedenaście dywizji piechoty po 3000-5000 bagnetów w stanach bojowych, co czyni w sumie od 33000 do 55000 bagnetów oraz 1800 szabel kawalerii" ${ }^{34}$. A na koniec, ulegając coraz modniejszym tendencjom pisania historii alternatywnej, dodaje zagadkowo: „Gdyby owe bagnety

34 T. Grzegorczyk, Wyprawa..., s. 45-46. 
i szable zostały użyte w koordynacji z polskim i ukraińskim wysiłkiem militarnym..." ${ }^{\prime 3}$.

W pracy naukowej nie ma potrzeby pisać ku pokrzepieniu serc i tworzyć całkowicie nierealne sojusze. Wiosną 1920 r. nie było żadnych szans na udział Litwinów w koalicji antysowieckiej. Narastał bowiem konflikt polsko-litewski, coraz ściślejsza była za to współpraca Litwinów z bolszewikami. W podgrzewaniu napięcia miała znaczący udział polska prasa, które na początku 1920 r. histerycznie twierdziła, że 30 tys. Litwinów jest gotowych do uderzenia na Wilno. W połowie marca 1920 r. sytuacja na linii rozdzielającej oba wojska uległa dalszemu zaostrzeniu, o czym świadczyły coraz częstsze zbrojne incydenty. Autor informuje o tym na s. 55 i w przypisie 146, co nie przeszkodziło mu wcześniej przekonywać o możliwości stworzenia polsko-litewskiego porozumienia skierowanego przeciwko sowieckiej Rosji.

Zdając sobie sprawę z niepewnej postawy Litwy, w marcu 1920 r. Naczelny Wódz, marsz. Piłsudski, przygotowując operację kijowską, musiał dokonać reorganizacji struktur dowódczych na wschodnim teatrze działań wojennych. Od 1 kwietnia za odcinek frontu nad Berezyną i Dźwiną odpowiadała 1 Armia gen. Stefana Majewskiego, natomiast Grupę „Wilno” przekształcono w 7 Armię pod dowództwem gen. Zygadłowicza. Jej zadaniem nadal było strzeżenie linii demarkacyjnej polsko-litewskiej. Zmienił się natomiast jej skład, gdyż po zabraniu 6 i 10 Dywizji Piechoty, posiadała tylko jeden związek taktyczny - 2 Dywizję Litewsko-Białoruską. Aż do początku lipca 1920 r. rozrzucone kordonowo pułki tej dywizji tworzyły osłonę od strony Litwy w pasie biegnącym od granicy z Prusami Wschodnimi na Suwalszczyźnie przez rejon Oran-Jewie-Szyrwint-Święcian, aż pod Dyneburg ${ }^{36}$.

Od wiosny 1920 r., czyli od momentu rozpalenia się walk polsko-sowieckich na niespotykaną wcześniej skalę, najpierw na Ukrainie, potem na Białorusi, Naczelnemu Wodzowi, marsz. Józefowi Piłsudskiemu zależało na uregulowaniu spornych kwestii z Kownem i zabezpieczeniu w ten sposób północnego skrzydła własnego Frontu Litewsko-Białoruskiego (od czerwca 1920 r. - Front Północno-Wschodni), który stanowił lewe skrzydło całego polskiego wschodniego frontu. Na żaden sojusz polsko-litewski

\footnotetext{
35 Ibidem, s. 46.

${ }^{36}$ M . Różycki, S. Dybkowski, Zarys historii wojennej 79-go Pułku Piechoty, Warszawa 1929, s. 20; Sz. Baron, Zarys historii wojennej 77-go Pułku Piechoty, Warszawa 1929, s. 13; S. Szabłowski, F. Suchomel, Zarys historii wojennej 78-go Słuckiego Pułku Piechoty, Warszawa 1929, s. 6-7..
} 
czy też na wielką koalicję Polski z państwami bałtyckimi, w której byłaby Litwa, jednak nie liczył w swoich kalkulacjach strategicznych. Litwini bowiem nie byli skłoni do rozmów i dokonywania zmian we wzajemnych stosunkach z Polską. Oceniali, że znacznie większe korzyści da im porozumienie z bolszewikami, z którymi już od 7 maja 1920 r. prowadzili w Moskwie rokowania pokojowe. Zależało im szczególnie na uznaniu de iure swego państwa przez Rosję Sowiecką oraz na załatwieniu swoich aspiracji terytorialnych. Dla Moskwy z kolei najważniejszą sprawą było odniesienie szybkiego zwycięstwa militarnego nad Polską. Wiedzieli bowiem, że po pokonaniu Polski osamotniona i słaba militarnie Litwa stanie się - podobnie jak Polska - kolejną republiką sowiecką. Dlatego też w tym momencie gotowi byli na daleko idące ustępstwa, aby doprowadzić do porozumienia z Litwą wrogo nastawioną do Rzeczpospolitej. Oczywiście, najlepszym dla nich rozwiązaniem był aktywny udział Litwy w wojnie przeciwko Polsce, który mógłby polegać np. na uderzeniu ich wojsk na północne skrzydło i tyły polskich związków operacyjnych zgrupowanych na Białorusi i północnej Wileńszczyźnie. Już na samym początku rozmów bolszewicy zaproponowali sojusz wojskowy przeciw Polsce. Litwini nie odrzucili tej propozycji, uważali jednak, że o sojuszu mogą rozmawiać dopiero po zawarciu traktatu pokojowego. Bolszewicy nie ustępowali i - jak informowała 12 maja 1920 r. delegacja litewska w Moskwie - „Proponują nam rozpocząć atak osiemnastego i zająć Wilno. Wówczas, nie czekając zakończenia rokowań, ogłoszą akt uznania [Litwy - W. R.]. Zaznaczamy, że w wypadku zajęcia Wilna przez bolszewików trudno będzie je odzyskać, dlatego należy zgrupować wojska w taki sposób, żebyśmy wcześniej zajęli gubernię wileńską" ${ }^{37}$.

Wiosenna ofensywa sowieckiego Frontu Zachodniego dowodzonego przez Michaiła Tuchaczewskiego na Białorusi rozpoczęła się 14 maja. Aby ją powstrzymać, marszałek Piłsudski polecił sformować nowy związek operacyjny - Armię Rezerwową pod dowództwem gen. Kazimierza Sosnkowskiego $^{38}$. Wkrótce pod naciskiem dwustronnej polskiej kontrofensywy dywizje sowieckie musiały rozpocząć odwrót na linię rzeki Auta, który zakończyły do końca pierwszej dekady czerwca. Litwini bardzo liczyli na sukces sowieckiego natarcia majowego. W depeszy skiero-

\footnotetext{
37 Č. Laurinavičius, Lietuvos-Sovietu Rusijos taiko sutartis, Wilno 1992, s. 133-134.

38 Więcej zob. J. Kirszak, Gen. Kazimierz Sosnkowski jako dowódca Armii Rezerwowej w roku 1920, [w:] Kazimierz Sosnkowski, żotnierz, humanista, maż stanu, w 120. rocznice urodzin. Materiały z konferencji we Wrocławiu, 17-18 listopada 2005, pod red. T. Głowińskiego i J. Kirszaka, Wrocław 2005, s. 28-43.
} 
wanej do swoich władz w Kownie delegaci litewscy w Moskwie radzili: „Powinniśmy wykorzystać dogodny moment, ale nie wcześniej, niż ujawnią się rzeczywiste zwycięstwa bolszewików, to jest gdy dojdą oni do linii Lida-Baranowicze"39. Plan ten trzeba było czasowo odłożyć, gdyż zaczęły nadchodzić wiadomości o niepowodzeniu sowieckiej ofensywy. Czekając na wyklarowanie się sytuacji militarnej, rząd litewski zawiesił rokowania z bolszewikami. Przerwa była jednak krótka. Rozmowy moskiewskie uległy przyspieszeniu na wieść o rozpoczęciu 4 lipca nowej ofensywy przez Front Zachodni Tuchaczewskiego. Już 12 lipca podpisano traktat pokojowy, w którym Rosja sowiecka uznawała samodzielność i niezależność państwa litewskiego. Określono także przebieg granicy litewsko-sowieckiej, wyjątkowo korzystny dla Litwy, gdyż otrzymywała ona nie tylko Wilno i Grodno, ale także Brasław, Postawy, Smorgonie, Oszmianę i Lidę.

Tomasz Grzegorczyk uważa, iż ,[...] moment wybuchu wojny [polsko-sowieckiej] jest kwestią dyskusyjną" (s. 35, przypis 66). Nie kwestionuje tego, iż 4 stycznia 1919 r. doszło pod Nową Wilejką do pierwszego zbrojnego starcia regularnego oddziału Wojska Polskiego (1 Pułk Ułanów Wileńskich) z siłami Armii Czerwonej (1 Pskowski Pułk Strzelców) ${ }^{40}$. Uważa jednak, iż nie można tej walki uznać za początek wojny polsko-sowieckiej, ponieważ „,...] rzeczywista organizacja [1 Pułku Ułanów Wileńskich] daleka była od wyczerpania znamion właściwych dla »regularneg«" pułku jazdy" (s. 35, przypis 66). W pierwszych miesiącach 1919 r. żaden z polskich pułków jazdy nie miał ,[...] znamion właściwych dla »regularnego« pułku jazdy". Miały bowiem ogromne braki kadrowe, a ubóstwo kraju nie pozwalało na ich szybkie uzbrojenie i wyekwipowanie. Szczególnie brakowało odpowiednich koni ${ }^{41}$. Gdyby przyjąć argumentację T. Grzegorczyka, że wojna zaczyna się wtedy, gdy oddziały mają „,regularną", czyli etatową postać, to trzeba by uznać, iż w latach 1919-1920 nie było wojny polsko-ukraińskiej, nie było także wojny polsko-sowieckiej.

W prowadzonych w naszym kraju od przeszło 25 lat badaniach wojny polsko-sowieckiej zasadniczą bazę źródłową dla gros badaczy stanowią materiały polskiej proweniencji. Niestety, wciąż wykorzystują oni te same, wielokrotnie analizowane zespoły akt, wydane drukiem źródła, a najczęściej ograniczają się tylko do przedwojennych opracowań. Nie

39 Č. Laurinavičius, op. cit., s. 135.

40 Szerzej zob. W. Rezmer, 4 stycznia 1919 roku-początek wojny Polski z Rosją Sowiecka, „Przegląd Historyczno-Wojskowy” 2009, nr 1, s. 55-68.

${ }^{41}$ Więcej na ten temat zob. A. Smoliński, Jazda Rzeczypospolitej Polskiej w okresie od 12 X 1918 do 25 IV 1920, Toruń 1999, s. 24153. 
prowadzą rzetelnej kwerendy w archiwach i bibliotekach rosyjskich oraz ukraińskich. Tylko niewielu sięga do akt zdeponowanych w Rosyjskim Państwowym Archiwum Wojskowym w Moskwie lub też do zasobów aktowych Centralnego Państwowego Archiwum Wyższych Organów Władzy i Administracji Ukrainy w Kijowie, gdzie są m.in. dokumenty Ministerstwa Wojskowego URL. W kijowskim archiwum znajdują się również dokumenty wytworzone przez poszczególne oddziały i związki taktyczne URL, które jako siły sojusznicze brały udział w operacji kijowskiej wiosną $1920 \mathrm{r}$.

Zasadniczą podstawą źródłową dla T. Grzegorczyka były również materiały przechowywane $\mathrm{w}$ archiwach polskich (Centralne Archiwum Wojskowe i Archiwum Akt Nowych w Warszawie). Ich uzupełnienie stanowiły źródła drukowane (zbiory dokumentów wydanych w Polsce, na Ukrainie i w Rosji, druki urzędowe, instrukcje i programy szkolenia, pamiętniki i wspomnienia, pięć organów prasowych wychodzących w 1920 r.- „Dziennik Powszechny”, „Gazeta Lwowska”, „Tygodnik Ilustrowany”, „Wiarus” i „Żołnierz Polski”). Sięgnięcie do drukowanych źródeł rosyjskich i ukraińskich pozytywnie wyróżnia bazę źródłową pracy T. Grzegorczyka od innych publikacji.

Nieźle wygląda także dobór opracowań, wśród których są publikacje zagraniczne: rosyjskie, ukraińskie, litewskie i angielskie. Można było oczywiście tę literaturę powiększyć, wykorzystując chociażby dzieła Tadeusza Machalskiego ${ }^{42}$, Zbigniewa Brochwicza-Lewińskiego ${ }^{43}$, Adama Przybylskiego ${ }^{44}$, Stanisława Rutkowskiego ${ }^{45}$, Aleksandra Smolińskiego ${ }^{46}$ czy też niedawno wydaną monografię Emiliana Wiszki ${ }^{47}$. Sporo wartościowych publikacji pojawiło się ostatnio na Ukrainie, np. artykuły Andrija Rukkasa $^{48}$. Można była także znacznie lepiej wykorzystać historiografię sowiecką, szczególnie z lat 20. i początku lat 30. XX w. Wtedy bowiem

42 T. Machalski, Z działań kawalerii podczas ofensywy na Ukrainie w 1920 roku: przykład dezorganizacji tyłów przeciwnika, „Przegląd Kawaleryjski” 1939, nr 7, s. 3-19 i nr 8, s. $147-158$.

43 Z. Brochwicz-Lewiński, Zagon na Koziatyn, „Bellona” 1921, t. 4, z. 4, s. 306-316.

44 A. Przybylski, Działania 1 dywizji piechoty Legionów na Ukrainie 1920 r., „Bellona” 1924 , t. 13 , z. 3, s. $236-252$, t. 14 , z. 1 , s. $53-69$ i z. 2, s. $161-176$.

${ }^{45}$ S. Rutkowski, Obrona Kijowa: ćwiczenia $i$ wykłady taktyki stosowanej na przykładzie bitwy polsko-rosyjskiej 1920 r., Warszawa 1932.

46 A. Smoliński, Jazda Rzeczypospolitej Polskiej w okresie od 12 X 1918 do 25 IV 1920, Toruń 1999.

47 E. Wiszka, Szósta Siczowa Dywizja Strzelecka Armii Ukraińskiej Republiki Ludowej. Formowanie. Szlak bojowy. Internowanie 1920-1924, Torun 2012, s. 10.

48 А. Руккас, „За нашу $і$ вашу свободу”. Спільніпо льско-украӥнські військові частини у війні 1920 р., Київська старовина 2003, nr 6. 
sowieccy oficerowie i historycy wojskowi sporo pisali na temat wojny z Polską w latach 1919-1920, poszukując źródeł klęski Armii Czerwonej. Szczególnie dużo wartościowych artykułów pojawiało się na łamach periodyku „Война и революция”49.

Opracowanie T. Grzegorczyka ma kilka mankamentów, które mogą utrudnić jego poprawny odbiór merytoryczny, szczególnie czytelnikom mniej zorientowanym w kwestiach organizacji wojska i nazewnictwa. Przykładem może być użyta w książce numeracja sowieckich armii. Dowiadujemy się więc, że dowódcą Frontu Południowo-Zachodniego „mianowano Aleksandra J. Jegorowa i podporządkowano mu armie XII, XIII oraz XIV" (s. 95-96). Nie jest to incydentalny przypadek. Autor bowiem w całej pracy uporczywie taką numerację stosuje. Tymczasem w Armii Czerwonej nie używano numeracji rzymskiej. Numeracja była arabska i to na wszystkich szczeblach, od związku operacyjnego do pododdziału. Autor powinien o tym wiedzieć, gdyż powołuje się na publikacje źródłowе Директивы командования фронтов Красной Арми і Директивы главного командования Красной Арми, a tam konsekwentnie numeracja jest arabska.

Trochę błędów jest w zapisie nazwisk. Na przykład Dowbór-Muśnicki J. (s. 238) - powinno być Dowbor-Muśnicki Józef; Wrangiel P. (s. 239) powinno być Wrangel Piotr. Na s. 54 pojawia się ,,minister Szaulis”, w rzeczywistości był to Jurgis Šaulys, poseł litewski w Berlinie, który przyjechał do Warszawy jako minister pełnomocny na rozmowy z rządem polskim.

W książce trafiają się także błędne zapisy bibliograficzne. Na przykład na s. 59-60 i 244 mamy: V. Lesčius, Lietuvos Ir Lenkijos Karinis Konfliktas Dèl Seinų Krašto 1919 Metais. Powinno być: V. Lesčius, Lietuvos ir Lenkijos Karinis konfliktas dẻl Seinų Krašto 1919 metais.

Mieczysław Cieplewicz, Andrzej Rzepniewski, Piotr Stawecki nie są autorami Zarysu dziejów wojskowości polskiej w latach 1864-1939 wydanych w Warszawie w 1990 r. (s. 249), jest to praca zbiorowa.

Praca T. Grzegorczyka posiada „Wykaz najczęściej występujących skrótów". Szkoda, że nie jest on kompletny. Skąd bowiem czytelnik ma wiedzieć, co oznaczają skróty UHA (zob. s. 81), CzUHA, HCzB (s. 144), ZURL (s. 78)? Jeżeli nie będzie zapoznawał się z treścią książki od samego

49 M.in.: Т. Хвесин, Действия Мозырской Группь в 1920 году, „Война и революция” 1928, nr 2, s. 113-131; С. Черенович, Тактические уроки отхода 3-й польской армии в июне 1920 2., „Война и революция” 1932, nr 1, s. 47-60; Ив. Кутяков, Оперативно-тактические уроки киевской перации 1920 г., „Война и революция” 1935, nr 2, s. 48-64. 
początku, będzie miał kłopot z ich rozszyfrowaniem. Będzie musiał wertować tekst, szukając fragmentu, gdzie występuje pełna nazwa.

Opracowanie Tomasza Grzegorczyka, to dzieło specyficzne, trudno je bowiem uznać za naukową syntezę ,wyprawy kijowskiej”. Przyjęta przez autora koncepcja pracy i konsekwentna jej realizacja sprawiły, że powstała książka o charakterze kompendium, przeznaczone zarówno dla przeciętnego czytelnika, ucznia, studenta, jak i dla początkującego badacza i profesjonalnego historyka zainteresowanych dziejami wojny polsko-sowieckiej w 1920 r. na Ukrainie i polsko-ukraińską współpracą wojskową. Zawarte $\mathrm{w}$ niej informacje, usystematyzowane chronologicznie i merytorycznie, będą z pewnością poddane wielu naukowym interpretacjom. Mimo sporych braków książka ułatwi także konstruowanie wniosków i ocen. A to z kolei będzie punktem wyjścia dalszych badań i porównań.

Waldemar Rezmer 